\section{Three Methods of Determining Diet, Utilization, and Trampling Damage on Sheep Ranges ${ }^{1}$}

\author{
WILLIAM A. LAYCOCK,2 HAYLE BUCHANAN, AND \\ WILLIAM G. KRUEGER
}

Principal Plant Ecologist, Intermountain Forest and Range Experiment Station, Forest Service, U.S. Department of Agriculture, Ogden, Utah; Associate Professor of Botany, Weber State College, Ogden, Utah; and Range Management Specialist, Oregon State University, Corvallis.

\section{Highlight}

Esophageal fistula sampling and ocular utilization estimates gave similar figures for dietary composition and for percentage utilization by sheep for most plant species in the tall-forb type. The paired-plot method gave higher utilization figures than the above methods because it estimated not only herbage eaten, but also that trampled. As a result, this method overestimated the dietary composition of species most susceptible to trampling damage; trampling accounted for one-half to two-thirds of the herbage removed by grazing.

Studies of sheep diet on rangeland generally are conducted to determine the quality and quantity of herbage eaten or the proportion of herbage eaten. Knowledge of what and how much herbage animals eat is needed for proper management of both the animals and the range. Discussions of the various methods used to study diet and utilization have been published [Smith et al., 1962; National Academy of Sciences-National Research Council (NAS-NRC), 1962; Martin,

\footnotetext{
${ }^{1}$ Received August 23, 1971.

${ }^{2}$ Stationed in Logan, Utah, at the Forestry Sciences Laboratory, maintained in cooperation with Utah State University.
}

1970; and others], but few studies have compared these methods.

The objective of this study was to compare three sampling methodsesophageal fistula; paired (caged and open) plot; and ocular utilization estimates-for determining botanical composition of the diet of sheep and the percentage of each plant species utilized on tall-forb range. The study also enabled us to estimate the amount of herbage trampled at different periods during the summer.

\section{Procedures}

Data reported here were obtained in conjunction with another study to determine daily and seasonal trends in the botanical and chemical composition of the diet of sheep on a tall-forb summer range. Details are reported elsewhere by Buchanan et al. ${ }^{3}$ and only information necessary for the comparisons made will be repeated here.

This study was conducted during the summer of 1967 on the U.S. Sheep Experiment Station ${ }^{4}$ summer range in southwestern Montana. The study area, located on a gentle, north-facing slope at an elevation of approximately $2,380 \mathrm{~m}(7,800 \mathrm{ft})$, had a fairly uniform cover of tall forbs dominated by sticky geranium. Six pastures, each 0.12 ha ( 0.3 acre) in size, were used-two each in early summer (mid-July), midsummer (early August), and late summer (late August). For comparisons of methods, data are presented only for the early summer trial in order

${ }^{3}$ Buchanan, Hayle, W. A. Laycock, and D. A. Price. Botanical composition and nutritive content of the diet of sheep at three periods during the summer on a tall-forb range in southwestern Montana. Intermountain Forest and Range Experiment Station, Ogden, Utah. (In preparation.)

${ }^{4}$ Range management research here is conducted cooperatively by the Intermountain Forest and Range Experiment Station of the Forest Service, the Animal Husbandry Research Division of the Agricultural Research Service, both U.S. Department of Agriculture, and the Agricultural Experiment Station of the University of Idaho. 
to reduce amount of tabular material. Data from all thrce periods are used to estimate forage intake and trampling damage.

\section{Clipped, Paired-Plot Method}

For each trial, 10 pairs of plots, $0.45 \mathrm{~m}^{2}\left(4.8 \mathrm{ft}^{2}\right)$ in size, were located on a restricted random basis in each pasture prior to grazing. All plots were marked and one of each pair was randomly selected to be caged. Plots were at least $3 \mathrm{~m}$ apart to minimize the effect of the cage on the open plot. Immediately after grazing, the 20 pairs of plots in the two pastures used in cach trial were clipped to ground level. The amount and percentage of each species removed from the open plots were calculated from the difference between herbage weight on caged plots and that on open plots. Total utilization calculated in this manner included herbage eaten plus that destroyed by trampling. 'Total dry weight production of each species on the caged plots was used as a control to compute utilization by the other methods.

\section{Esophageal Fistula Method}

Seven esophageally fistulated sheep were used (four in one pasture and three in the other) during each 6-day grazing trial to collect samples representative of the diet. Three samples taken on alternate days were used for analysis of botanical composition. Data presented are combined from the two pastures used simultaneously in each trial. Total fecal output was collected from four bagged yearling wethers (two in each pasture) that grazed with the fistulated sheep. Amount of acid-detergent fiber in fistula and fecal samples was determined (Van Soest, 1963) and dry-matter intake was calculated by the lignin-ratio technique (Forbes and Garrigus, 1948).

Total grazing pressure was 250 300 sheep days per ha (100-120 sheep days per acre), a rate similar to that on adjacent herded ranges. The average dry-matter intake per sheep per day multiplied by the total number of days all sheep grazed provided an estimate of the total dry weight of forage consumed per trial in each pasture.

Microscopic point sampling was used to obtain the percentage composition of each species found in the fistula samples. In order to compare results of the three methods, the composition of fistula samples was converted from a surface area basis to a weight basis. The weight: surface area ratios calculated for the same plant species by Krueger (1970) were used to make the conversion. This method indirectly determines composition by weight. Hand separation of fistula material (Leigh and Mulham, 1966), the only direct method, was considered too time consuming and laborious for this study.

To obtain percentage utilization for each species, the total dry weight intake of all sheep for the entire trial was converted to intake by species according to percentage composition in fistula samples. This amount, expressed as a percentage of the total amount of each species produced on the 20 caged plots, was an estimate of utilization. Because of the number of steps and the sampling errors associated with cach, utilization figures obtained by this method probably are much less reliable than those given by the other two methods.

\section{Ocular-Estimate-by-Plot Method}

Percentage utilization by weight was estimated immediately after grazing in each trial, by the ocularestimate-by-plot method (Pechanec and Pickford, 1937). The average utilization for each species was computed for eighty $0.45-\mathrm{m}^{2}$ plots (40 in each pasture). In each trial, this percentage multiplied by the average dry-weight production of each species from the 20 cage plots was an estimate of the total amount eaten. The percentage each species contributed to the diet was also computed.

Results and Discussion Clipped, Paircd-Plot Mcthod

Generally, the botanical composition of the diet estimated from paired-plot clippings was similar to that obtained by the other methods (Table 1). Major exceptions were: yarrow and sticky geranium, which had considerably higher dietary composition estimates; and northwest cinquefoil, which had lower dietary composition estimates from clipped plots.

The paired-plot method consistently gave higher utilization percentages than the other methods because the difference between the caged and open plots represented not only herbage eaten by the sheep, but also that destroyed by them in other ways (c.g., trampling). Deer or other game animals did not use any forage in the pastures. Utilization by insects and rodents and normal loss of plant parts by shattering or lodging might affect the difference; however, these factors should have about the same effect on both plot types. Cages were in place only 8 days; so any changes in growth as the result of microclimatic alterations should be minimal.

\section{Esophageal Fistula Method}

Because fistula samples were a portion of the sheep's actual diet, this method was the standard against which diet computed by the other two methods was compared. These comparisons are presented under the discussions for the other methods.

Estimates of utilization determined from fistula samples were not always realistic. For some highly palatable species, such as pale agoseris, mountain sorrel, and thickleaf groundsel, estimates of the amount of a particular species eaten sometimes were greater than the total amount of that species produced on the caged plots (designated by $100+$ in the Utilization by Weight section of Table 1). This situation possibly resulted from inaccurate production estimates due to the relatively low number of caged plots used. The 20 plots used for each trial gave reasonably precise estimates of the total green herbage present; the half-confidence interval in the early summer trial 
was $16 \%$ of the mean at the $95 \%$ confidence level. However, for some of the less abundant species the half-confidence interval was larger. It was $35 \%$ of the mean for pale agoseris, which had a frequency of occurrence in the plots of $80 \%$. The half-confidence interval was considerably higher for mountain sorrel and thickleaf groundsel, both of which had low frequencies $(30 \%$ and $10 \%$, respectively).

\section{Ocular-Estimate-by-Plot Method}

The percentage utilization and the botanical composition of the diet indicated by ocular estimates generally were similar to figures obtained by the fistula method (Table 1). Major exceptions were: low estimates of both utilization and diet for mountain knotweed. The reason was learned only after fistula samples were examined. Sheep pulled many of these annuals from the ground and consumed roots, stems, and leaves. Few partially eaten stems remained; consequently, utilization estimates were inaccurate.

The ocular-estimate-by-plot method was fastest, both in field and computation time. However, considerable training is necessary to achieve proficiency and observer bias can also affect accuracy of data (Smith et al., 1962). A major disadvantage of the method is the possibility of bias when a positive or negative correlation exists between amount eaten and amount present. To get unbiased estimates, each utilization estimate must be weighted by production on the same plot (Smith, 1968). However, in the tallforb type, this technique would only partially correct estimates. "Invisible" utilization (use by sheep that is not readily discerned), such as that described for mountain knotweed, would not be detected by this technique. Reasonable estimate of this type of utilization can only be obtained from comparisons of caged and open plots or from careful observations on the same plots before and after grazing. Weighted production values would also be biased by the amount of herbage trampled and overlooked by estimators. Some trampled herbage "disappears" when it is mixed with the litter or loose soil. Careful observations probably would have separated some of the recently trampled material from the previous year's litter.

\section{Intake}

Results of all methods showed a stable or slightly increased dryweight intake from early to late summer (Table 2). The NAS-NRC (1957) suggested $1.8 \mathrm{~kg}$ per day of air-dry feed for the class of sheep (50-kg rams) most comparable to our test animals. The intake computed by the clipped plot method was higher than this because trampling losses were included in the figure. Intake from the ocular estimate method is lower than the NAS-NRC's suggested intake because utilization estimates for some plant species probably were low due to "invisible" utilization. The reason for low intake figures from fistula and fecal samples is not known; however, salivary wetting followed by drying may have artificially increased the apparent amount of lignin in fistula samples as suggested by Lesperence and Bohman (1964). Such an increase in lignin would decrease the feces:

Table 1. Air dry herbage production (kg/ha, air-dry), utilization (\% by weight), and botanical composition (\%) of the diet of sheep in early summer as determined from fistula samples, clipped plots, and ocular utilization estimates on plots.

\begin{tabular}{|c|c|c|c|c|c|c|c|}
\hline \multirow[b]{2}{*}{ Species } & \multirow{2}{*}{$\begin{array}{c}\text { Air-dry } \\
\text { herbage } \\
\text { production }\end{array}$} & \multicolumn{3}{|c|}{ Utilization } & \multicolumn{3}{|c|}{ Botanical composition of diet } \\
\hline & & Fistula & $\begin{array}{l}\text { Clipped } \\
\text { plots }\end{array}$ & $\begin{array}{l}\text { Estimated } \\
\text { plots }\end{array}$ & Fistula & $\begin{array}{l}\text { Clipped } \\
\text { plots }\end{array}$ & $\begin{array}{l}\text { Estimated } \\
\text { plots }\end{array}$ \\
\hline Total grass 1 & 205 & 30 & 49 & 28 & 16 & 10 & 12 \\
\hline Yarrow (Achillea millefolium) & 81 & 4 & 57 & 1 & 1 & 5 & $\mathrm{t}^{2}$ \\
\hline Pale agoseris (Agoseris glauca) & 65 & 35 & 77 & 40 & 6 & 7 & 10 \\
\hline Leafybract aster (Aster foliaceus) & 37 & 66 & 50 & 37 & 6 & 1 & 3 \\
\hline Thickstem aster (Aster integrifolius) & 114 & 8 & 80 & 48 & 2 & 6 & 8 \\
\hline Sticky geranium (Geranium viscosissimum) & 899 & 1 & 23 & 3 & 2 & 28 & 8 \\
\hline Stickseed (Hackelia floribunda) & 21 & 31 & 54 & 21 & 2 & 2 & 1 \\
\hline Mountain knotweed (Polygonum montanum) & 83 & 25 & 43 & 2 & 5 & 4 & $\mathrm{t}$ \\
\hline Northwest cinquefoil (Potentilla gracilis) & 476 & 26 & 37 & 42 & 32 & 17 & 45 \\
\hline Mountain sorrel (Rumex paucifolius) & 16 & $100+$ & 78 & 54 & 7 & 3 & 5 \\
\hline Thickleaf groundsel (Senecio crassulus) & 2 & $100+3$ & 7 & 63 & 5 & $\mathbf{t}$ & $\mathrm{t}$ \\
\hline Other forbs & 221 & 27 & 65 & 12 & 16 & 17 & 8 \\
\hline Total forbs & 2,015 & 16 & 39 & 16 & 84 & 90 & 88 \\
\hline All vegetation & 2,200 & 17 & 40 & 17 & 100 & 100 & 100 \\
\hline
\end{tabular}

${ }_{1}$ Grass species were not differentiated in fistula samples.

a Less than $0.5 \%$ of the diet.

${ }^{3}$ Utilization of $100+\%$ indicates more herbage was found in the fistula samples than the caged clipped plots indicated was present in the pasture. 
Table 2. Comparison of amount of air-dry forage eaten $(\mathrm{kg} / \mathrm{sheep} / \mathrm{day})$ computed from fistula and fecal samples, clipped plots, and utilization estimates.

\begin{tabular}{lccc}
\hline \hline \multicolumn{1}{c}{ Method } & $\begin{array}{c}\text { Early } \\
\text { summer }\end{array}$ & Midsummer & $\begin{array}{c}\text { Late } \\
\text { summer }\end{array}$ \\
\hline Fistula and fecal samples & 0.9 & 1.1 & 1.1 \\
Paired, clipped plots & 2.3 & 3.1 & 2.3 \\
Utilization estimates & 1.0 & 1.0 & 1.1 \\
\hline
\end{tabular}

fistula lignin ratio and the intake value.

\section{Trampling Losses}

Trampling losses were considered to be the total amount of forage removed minus the amount eaten. The total amount removed was the difference between the amounts of herbage on caged and open plots and the amount eaten was the intake calculated from fistula and fecal samples (Table 3). Approximately one-half of the total herbage removed in early and late summer was eaten, one-half was destroyed by trampling. Trampling damage was most severe in midsummer when it accounted for approximately two-thirds of the herbage removed. By early August, all forbs had reached maximum height and were still quite succulent. Consequently, they were particularly susceptible to being knocked over or otherwise damaged by the sheep.

Sticky geranium was the major species affected by trampling. Of the total weight of forbs lost by

trampling, this species made up $43 \%$ in early summer, $70 \%$ in midsummer, and $26 \%$ in late summer. Sticky geranium contributed 30 $40 \%$ of the herbage present, but was unpalatable to the sheep. Stems apparently were knocked down or broken off by animals as they foraged. Yarrow, which has rather slender, easily broken leaves, was also severely affected by trampling. Thickstem aster was damaged by trampling in the early summer trial. Alpine leafybract aster, which flowers in middle to late summer, was damaged by trampling in late summer.

The trampling loss figures in Table 3 may be too high because intake figures might be low. However, even if the amount of feed is increased to the suggested NASNRC level, $14 \%$ to $40 \%$ of the total forage removed can be attributed to trampling. A more sophisticated study design would help to more accurately determine trampling losses in this vegetation type.

In most grazing studies the
Table 3. Comparison of amount (kg/ha and \%) of dry matter eaten and trampled by sheep on tall-forb range.

\begin{tabular}{|c|c|c|c|c|}
\hline \multirow[b]{2}{*}{ Trial } & \multirow[b]{2}{*}{ Class } & \multicolumn{3}{|c|}{ Dry matter removed } \\
\hline & & Eaten $^{1}$ & Trampled $^{2}$ & Total $^{3}$ \\
\hline Early summer & $\begin{array}{l}\text { Grass } \\
\text { Forb } \\
\text { Total }\end{array}$ & $\begin{array}{c}62(61)^{4} \\
325(41) \\
387(43)\end{array}$ & $\begin{array}{r}39(39) \\
471(59) \\
510(57)\end{array}$ & $\begin{array}{l}101 \\
796 \\
897\end{array}$ \\
\hline Midsummer & $\begin{array}{l}\text { Grass } \\
\text { Forb } \\
\text { Total }\end{array}$ & $\begin{array}{r}26(55) \\
310(36) \\
310(36)\end{array}$ & $\begin{array}{r}21(45) \\
544(64) \\
565(63)\end{array}$ & $\begin{array}{r}47 \\
901 \\
901\end{array}$ \\
\hline Late summer & $\begin{array}{l}\text { Grass } \\
\text { Forb } \\
\text { Total }\end{array}$ & $\begin{array}{r}24(12) \\
395(62) \\
419(51)\end{array}$ & $\begin{array}{l}168(88) \\
242(38) \\
410(49)\end{array}$ & $\begin{array}{l}192 \\
637 \\
829\end{array}$ \\
\hline
\end{tabular}

${ }_{1}$ Amount eaten by sheep, calculated from fistula and fecal samples.

${ }^{2}$ Amount trampled $=$ total removed minus amount eaten.

'Total amount removed, based on difference between herbage weights on caged and open plots.

- Figures in parentheses are values expressed in percent. amount of herbage lost by trampling has been all but ignored. Brown (1954) and Wagner et al. (1950) discussed trampling loss as a factor that complicates evaluation of herbage consumption on cultivated pastures, but they gave no quantitative data. Grelen (1967) found that utilization based on production inside and outside stationary cages on pine-bluestem ranges was greatly overestimated when grazing was heavy, but he did not attribute any of the error to trampling loss. Quinn and Hervey (1970) measured trampling loss on a sandhills grass range at $22 \mathrm{~kg} / \mathrm{ha}(1 \%$ to $5 \%$ of the standing crop). This loss is small compared with the 410 to $465 \mathrm{~kg}$ per ha (17\% to $23 \%$ of the standing crop) trampled in the present study. Differences in vegetation type (sod versus tall forb) and the animal type (cattle versus sheep) probably account for variances in the amounts trampled in the two studies.

The difference in amount of herbage present on caged and open plots was the method suggested for calculating the intake of grazing animals in the International Biological Program (Milner and Hughes, 1968). Correction for increased growth rate in areas caged for long periods was also suggested for IBP studies, but the authors did not propose any correction for trampling losses. In some vegetation, such as the tall-forb type, trampling losses may be substantial, so the difference method overestimates total intake and gives a biased estimate of the botanical composition of the diet.

Various studies to ascertain the effect of trampling on amount of litter and on soil characteristics were reviewed by Lull (1959) and by Reynolds and Packer (1962). However, few studies to determine the effect of trampling on subsequent production have been conducted. Packer (1953) found that trampling by means of an "artificial hoof" had the immediate effect of reducing ground cover on wheatgrass and cheatgrass ranges, but he did not determine the effect on 
production or cover in following years. By artificially flattening the stems of tall bluebell (Mertensia arizonica var. leonardi) during the early flowering and fruiting stages for 4 consecutive years, Laycock and Conrad (1969) found that herbage production was reduced by approximately $50 \%$. Similar studies for other species are needed to clarify the effect of trampling upon herbage production and vigor.

\section{Conclusions}

1. The esophageal fistula method is the most accurate method tested for determining the actual composition (either botanical or chemical) of the diet of sheep; however, it is extremely time consuming, both in the field and in the laboratory. For this reason, it is basically a research tool and not a technique suitable for actual range management operations. The fistula method does not accurately measure the total impact of grazing on the range because it accounts only for forage consumed and not for other losses, such as trampling. Utilization percentages of individual species are also inaccurate because of the number of steps and associated sampling errors involved in the calculation.

2. The difference in amount of herbage on paired, clipped plots is the best method for measuring the total impact of grazing on the range because it measures total herbage loss, both by consumption and by trampling. However, it is also time consuming. Because trampling losses are included, it is not a good method for determining the botanical composition of the actual dict of sheep. Plant species susceptible to trampling will be overrepresented in the diet.

3. The ocular-estimate-by-plot method probably is the best compromise for determining both diet and utilization on large-scale range operations. It is rapid to use and yields relatively reliable data for most plant species. Whenever possible, utilization estimates should be weighted by herbage production on the same plots (Smith, 1968).
Also important are adequate training, procedures to minimize the effect of personal bias, and other techniques to improve the method suggested by Smith et al. (1962). Observations before and after grazing or comparisons of production on protected and grazed areas should be made to minimize the errors caused by "invisible" utilization.

4. Studies are needed to determine the amount of trampling damage that occurs in different vegetation types and the effect of trampling on production and vigor of individual species. With this information, management systems could be devised to minimize trampling damage and thus make more efficient use of rangelands.

\section{Literature Cited}

Brown, Dorothy. 1954. Methods of surveying and measuring vegetation. Commonwealth Bur. Pasture and Field Crop Bull. 24. 223 p.

Forbes, R. M., ANd W. P. Garrigus. 1948. Application of a lignin ratio technique to the determination of the nutrient intake of grazing animals. J. Anim. Sci. 7:373.

Grelen, Harold E. 1967. Comparison of cage methods for determining utilization on pine-bluestem ranges. J. Range Manage. 20:94-96.

Krueger, William C. 1970 . Relationships of the special senses to forage selection. Ph.D. Diss., Utah State Univ., Logan, Utah. 87 p.

Laycock, W. A., and P. W. Conrad. 1969. How time and intensity of clipping affect tall bluebell. J. Range Manage. 22:299-303.

Leigh, J. H., and W. E. Mulham 1966. Selection of diet by sheep grazing semi-arid pastures on the Riverine Plain. I. A bladder saltbush (Atriplex vesicaria)-cotton bush (Kochia aphylla) community. Australian J. Exp. Agr. and Anim. Husb. $6: 460-467$.

Lesperence, A. L., ANd V. R. Bohman. 1964. Chemical changes in forage induced by sample preparation. West. Sec. Amer. Soc. Anim. Sci. Proc. 15:54.

LulL, H. W. 1959. Soil compaction on forest and range lands. U.S. Dep. Agr. Misc. Pub. 768, 33 p.

Martin, S. Clark. 1970. Relating vegetation measurement to forage consumption by animals. P. 93-100, in: Range and Wildlife Habitat Evaluation-a Research Symposium. U.S. Forest Serv. Misc. Pub. 1147.

Milner, G., AND R. E. Hughes. 1968. Methods for the measurement of the primary production of grassland. Int. Biol. Program Handbook 6, 70 p. Blackwell Sci. Publications, Oxford.

National ACademy of SGiences-National Research Council. 1957. Nutrient requirements of domestic animals: No. 5, nutrient requirements of sheep. Nat. Acad. Sci.-Nat. Res. Counc. Pub. 504, Wash., D.C. $33 \mathrm{p}$.

National Academy of ScIEnces-National Research Council. 1962. Basic problems and techniques in range research. Nat. Acad. Sci.-Nat. Res. Counc. Pub. 890, Wash., D.C. $341 \mathrm{p}$.

Packer, Paul E. 1953. Effects of trampling disturbance on watershed conditions, runoff, and erosion. J. Forest. 51:28-31.

Pechanec, J. F., and G. D. Pickford. 1937. A comparison of some methods used in determining percentage utilization of range grasses. J. Agr. Res. 54:753-765.

Quinn, James A., AND Donald F. Hervey. 1970. Trampling losses and travel by cattle on sandhills range. J. Range Manage. 23:50-54.

Reynolds, Hudson G., and Paul E. Packer. 1962. Effects of trampling on soil and vegetation. P. 116-122, in: Range Research Methods: A Symposium, Denver, Colo., May 1962. U.S. Dep. Agr. Misc. Pub. 940.

SMITH, Dixie R. 1968. Bias in estimates of herbage utilization derived from plot sampling. J. Range Manage. 21:109-110.

Smith, Divight R., P. O. Curie, J. V. Basile, and N. C. Frischinecht. 1962. Methods for measuring forage utilization and differentiating use by different classes of animals. P. 93102, in: Range Research Methods: A Symposium, Denver, Colo., May 1962. U.S. Dep. Agr. Misc. Pub. 940. VAN Soest, P. J. 1963. Use of detergents in the analysis of fibrous feeds, II. A rapid method for the determination of fiber and lignin. J. Assoc. Offic. Agr. Chem. 46:829.

Wagner, R. E., M. A. HeIN, J. B. ShePherd, ANd R. E. Ely. 1950. A comparison of cage and mower strip methods with grazing results in determining production of dairy pastures. Agron. J. 42:487-491. 